\title{
Professor Emérito Philomeno Joaquim da Costa
}

\begin{abstract}
Em sessão solene realizada aos 9 de outubro de 1980, no Salão Nobre da Faculdade de Direito, a Congregação dos Professores outorga mais um título de Professor Emérito a um de seus ilustres membros, PhIlomeno JoAquim DA Costa. Os Professores Oscar Barreto Filho, Jose Cretglla JúnIOR e JoSÉ AFronso DA SHVA introduziram o novo Emérito no doutoral. Proferiu o discurso de saudação o mestre JoÃo BATISTA DE OLIVEIRA e COSTA Júnior, que rememorou os feitos notáveis da longa carreira docente e profissional do Professor PHIOMENo, palmilhada com entusiasmo e probidade, que sempre caracterizaram sua personalidade invulgar. agora coroada pelo mais alto galardăo da vida universitária. Diz o Professor Costa "A douta Congregação da Faculdade de Direito reconhece os altos méritos de V. Excia., mantidos intocáveis durante toda a vossa longa atividade professoral e profissional, em linba reta, sem tergiversações, temperada na mais rija força do saber e da lealdade". O Professor PrnoMENo agradeceu a homenagem com um interessante discurso, em que expõe sua alma de jurista, de professor, político e a de um simples cidadão. porém repleto de sentimentos.
\end{abstract}

\section{A Sessão solene}

Aos 9 de outubro de 1980 , às 20,30 horas, estando a Congregação reunida no Salão Nobre, os professores OSCAR BARReto Filho, José Cretella Júnior e José Affonso da Silva introduziram no doutoral o Novo Professor Emérito PHILOMENo JOAQUIM DA COSTA.

O Professor JoÃo BATISTA dE OLIVEIRA e COSTA JÚNIOR saudou o homenageado, reconhecendo-lhe as qualidades de retidão e honestidade que sempre nortearam sua vida, repleta de vitórias profissionais. Respeitado pelos colegas de profissão, ocupou, entre outros cargos, o Conselho da $O A B$, a vice-presidência do Instituto dos Advogados, representou o Brasil em congressos internacionais, etc.

O eloqüente discurso do Professor PhILOMENo foi interessantemente dividido em 4 partes, nas quais, em $1 .^{\circ}$ lugar, ele se pronunciou como jurista, opinando pela subjetivação da empresa, entendendo que "tarda a consagração de um grupo de atividades econômicas ter a qualidade de um ente independente, capaz de direitos e obrigações"

Posteriormente, falando como professor, entendeu que o ensino superior demanda urgentemente o estabelecimento de 
sua autenticação; como político, o Professor Philomeno julga que o país necessita retornar logo a uma democracia sem adjetivos e finalmente, como cidadão ele combate os extremismos, esclarecendo sua posição em função da Academia : "numa escola de Ciências Jurídicas, não se pode tolerar a implantação de regime de força"

Agradece comovido o discurso do Professor Costa JÚnion, esclarecendo que é para ele uma honra tê-lo como colega, recompensa tê-lo como amigo e felicidade ser por ele saudado.

Demonstrou plenamente sua poética alma de jurista, consciente e honesta, e finalizou apresentando a todos a segurança de seu profundo reconhecimento.

Foi grandemente aplaudido o discurso do Novo Professor Emérito, por todos os presentes, seus colegas, amigos, alunos e ex-alunos e a Diretoria, que, a final, deu por encerrado o evento.

A seguir, publica-se o discurso de saudação do Professor Costa Júnior, e o discurso do Professor Philomeno JoAquim DA COSTA.

\section{Discurso de João Batista de Oliveira e Costa Júnior}

Há convites que se não recusam; obriga-nos o passado pleno de sentimentos, os quais o tempo não consegue desgastá-los nem diminuir-lhes os efeitos, ao contrário, os reforçam e alcandoram tanto mais quanto se caminha na estrada da vida.

Por isso a minha presença, nesta tribuna, não necessita de justificações especiais, quando outros oradores, com maiores virtudes, melhor desincumbir-se-iam da tarefa que me foi atribuída; porém, acredito, ninguém poderia exceder-me na admiração e amizade que sempre me vincularam ao Professor Philomeno JoAquim da Costa.

É, portanto, com imensa alegria que vos dirijo, neste instante, Professor Philomeno, a saudação cordial e de reconhecimento de vossos pares, pedindo escusas se as minhas palavras não corresponderem às exigências da sábia congregação nem às expectativas do ilustre homenageado.

A outorga do título de professor emérito é realmente de valor inexcedível - coroamento de uma longa atividade no magistério superior, palmilhado com entusiasmo e probidade, 
que sempre caracterizaram a personalidade invulgar de PHILOMENO JOAQUIM DA COSTA.

Se a concessão dessa láurea muito enobrece e vos dá ainda todas as honras do cargo que exercestes antes da jubilação, é porque a douta Congregação da Faculdade de Direito da Universidade de S. Paulo reconhece os altos méritos de V. Exa., mantidos intocáveis durante toda a vossa longa atividade professoral e profissional, em linha reta, sem tergiversações, temperada na mais rija forja do saber e da lealdade.

Formado pela Faculdade de Direito da Universidade de S. Paulo, em 1929, com curso de doutorado nos anos de 1951 e 1952, sois dos mais brilhantes advogados de nossa terra e patrocinais junto ao Poder Judiciário, com dedicação, aqueles que têm direito à defesa de seus interesses verdadeiros, para que a justiça paire soberana acima de tudo e de todos. Tal atividade, entretanto, subordinastes-a sempre à ética profissional ou moral prática, que em última análise é o exercício do bem, isto é, o costume e o hábito de direitos e deveres.

Mantivestes sempre fiel a essas diretrizes que, também, representam as normas impostas pela vossa própria consciência, defendendo com extrema bravura os bens que lhe são confiados, como exemplo do advogado honesto e conhecedor profundo de todos os meandros do Direito. Desempenhais com dignidade e proficiência a advocacia, atendendo ao chamamento interior de vossa vocação, realizando-se e exteriorizando ao mesmo tempo a inteligência e a generosidade, que preenchem o vazio e elevam o homem. E essa fidelidade à vocação que torna o profissional fulcro do bem comum e alento para todas as esperanças das pessoas mais ávidas e necessitadas de amor e Justiça.

Advogar é lutar, identificando-se com o patrocinado para vencer uma verdadeira batalha, embora em termos corteses e sem derramamento de sangue. Para isso é necessário o saber, o estudo da doutrina, o conhecimento do direito comparado e do suporte de um direito subjetivo; porém, mais sedutora é a pesquisa do fundamento da própria norma, que leva à esfera da filosofia. Daí, quanto mais perfeitas as leis tanto menores serão as demandas. É esse direito que acompanha o homem antes do nascimento, na proteção do nascituro - "Homo est quid futurus est", na expressão de Tertuliano, e até depois da morte, no reconhecimento da vontade manifesta pelo testador. 


\section{4}

As leis que regulam os limites entre as atividades e os deveres do homem são de índole moral, deveres esses que integram o Direito Natural. Eis porque a concepção do Direito repousa na existência de uma lei moral como norma de conduta e na liberdade de o homem condicionar-se a essa lei. Quando se reconhece um direito, admite-se a idéia de justiça, a qual pressupõe a existência da lei moral. Justiça, segundo o Direito Romano - perdoem-me a ousadia, que poderá gerar o erro é a vontade firme e durável de dar a cada um o que é seu: "Constans et perpetua voluntas suum cuique tribuendi"

Todavia, é indispensável, para o seu exercício, o "savoir faire" para transigir no momento útil e necessário, porque na sociedade, em todas as atividades humanas, será a prática de uma virtude, uma conveniência lícita. Lembremo-nos, pois, da prudência do Imperador do Brasil recomendando ao conselheiro Pimenta Bueno "que formulasse um plano de emancipação sem grande abalo para o país", o que não seria capitular porque, na verdade, o equilíbrio e o bom senso indicam que o homem, em muitos momentos, não pode mais retroceder, nem parar, nem precipitar-se - "Natura non facit saltus"

E a ciência, atividade humana mais absorvente deste século, com a consciência que conduz à sabedoria.

Quando todas as ilusões se desvanecem; quando o sofrimento parece irresistível; e quando o desalento começa a dominar o ser carente de justiça e vítima do espoliador insaciável é o advogado que lhe renova as esperanças e luta denodadamente para que lhe seja devolvido o bem usurpado e volte a alegria, há tempo esquecida, restabelecendo o direito sagrado e indivisível, que nunca lhe poderia ter sido negado.

Que nobreza de profissão! Que sacerdócio da Justiça! Que apostolado do bem comum!

Vós sois, Prof. Emérito Philomeno JoAquim DA CosCa, esse advogado cônscio dos deveres, que jamais fostes suplantado no saber, na coragem e honestidade, pois já assinalastes as mais brilhantes vitórias nos pretórios para gáudio dos patrocinados e prestígio de vossa banca de advocacia.

Respeitado pelos colegas, figurantes no Conselho da Ordem dos Advogados, onde defendestes com insistência os interesses de vossos colegas e da profissão, impondo-se pela clareza nos debates e pelo acerto de todas as vossas proposições. Fostes eleito vice-presidente do Instituto dos Advogados; presidente da Comissão de Direito Comercial ; membro da Comissão examinadora do Concurso de Estudos Jurídicos desse Instituto; e 
membro da Comissão examinadora dos candidatos à magistratura. Como delegado do Instituto dos Advogados, participastes, na qualidade de representante do Brasil, de congressos internacionais, como os de Santiago, Lisboa, Paris e da Subseção de Direito Comparado da Seção de Ciências Jurídicas da Unesco.

Anote-se, ainda, que V. Exa. preside, desde 1969, o Instituto de Direito Comercial Comparado e Biblioteca Tullio Ascarelli; e desempenhastes o cargo de Presidente reeleito do Instituto Paulista de Contabilidade, atual Sindicato dos Contabilistas, diplomado que sois, também, pela Escola de Comércio "Alvares Penteado"; de diretor da Revista dos Tribunais, de 1933 a 1951; e diretor da Revista de Direito Mercantil, em 1971.

Com tal conhecimento e representatividade, destacastes como uma das mais legítimas expressões da magnífica classe dos advogados de nossa terra.

Ingressastes no magistério superior em 1957, obtendo o título de livre docente de Direito Comercial de nossa Faculdade, tendo apresentado a magnífica monografia sobre "Autonomia do Direito Comercial".

Conseguistes com destacado brilho a cátedra da mesma disciplina em 1965, após concurso memorável, apresentando a tese sobre "Operações da Anônima com as Ações do Seu Capital", defendendo-a com ardor e sabedoria, encantando o auditório pela agilidade da inteligência e profundeza de conhecimentos.

Sucedestes com todos os méritos o saudoso professor HONÓRIO MONTEIRO.

Definistes as características do professor no discurso de agradecimento, dizendo da obrigação de fazer voto de humildade e da condição de ser autêntico, reconhecendo o sacerdócio do magistério e afirmando que o seu exercício constitui "uma atividade religiosa pela crença na eternidade do Direito"

Homenageastes, muito tempo depois, no corrente ano a vossa "indômita Academia", dedicando-lhe o livro "Anotações às Companhias" - Vol. I - a respeito da Lei 6.404 de 15 de dezembro de 1976, que dispõe sobre as sociedades por ações, obra de fôlego, de mais de 500 páginas, nas quais deixastes impressas a clareza de vosso espírito, a ordenação precisa e a argúcia do hermeneuta esclarecido, ao comentar os artigos $1 .^{\circ}$ a 27 da referida lei. 
Dir-vo-las-ei eu, também, da imensa responsabilidade que pesa sobre os ombros do professor, tornando-o não só o expositor de assuntos científicos, se não, e principalmente, o plasmador de novas gerações que reflitam, no futuro, a cultura e o ideal que sempre acalentaram os mais puros anseios do mestre.

Lembrar-vos-ei eu ainda, com Demóstenes, o insuperável tribuno ateniense, que se deve procurar, como escola para o vindouro, inspirar-se nos exemplos das mais belas ações do passado: o que se conhece hoje encontra suas raízes mais longínquas no pretérito e constituir-se-á em seiva vivificante para o futuro.

Exercestes, também, o cargo de professor de Direito Comercial na Faculdade de Direito da Universidade Mackenzie; de professor de Direito Industrial na Faculdade de Direito da Universidade de Campinas; regestes as cadeiras de "Sociedades Anônimas em Direito Comparado" e de "Técnica Jurídica do Desenvolvimento" no Curso de Especialização e depois nos Cursos de Pós-Graduação da Faculdade de Direito da Universidade de S. Paulo.

Cavaleiro andante com a missão de ensinar, incutistes sempre no espírito de nossa juventude a ciência pura e verdadeira e, mais do que isso, fostes um paradigma de honradez, dignidade e coragem em todos os instantes de vossa gloriosa atividade no magistério superior.

No período entre os dois concursos, publicastes o ensaio sobre: "O Silêncio nos Negócios Jurídicos", em comemoração ao $500^{\circ}$ aniversário da Revista dos Tribunais, no ano de 1962 ; a monografia: "As Partes Benificiárias", em homenagem à memória de TUllio AsCARELli; e anteriormente, o estudo sobre: "Prescrição - Pacto - Encurtamento de seu Prazo - Validade"; o ensaio sobre: "Sociedades por Ações Conselho Fiscal — Seu Inteiro Descrédito - Substituição das Funções pela Revisão de Contas - Legislação Comparada", apresentado à III Convenção Nacional de Contabilistas e que foi publicado na Revista dos Tribunais e na Revista Forense; o ensaio sobre: "Vendas com a Cláusula Cif", transcrito em várias revistas, inclusive na Revista da Faculdade de Direito de Montevidéu; o ensaio sobre as "Sociedades Anônimas", apresentado à VIII Conferência Interamericana de Advogados; o ensaio sobre as "Sociedades Financeiras"; e posteriormente muitos outros trabalhos, resenhas bibliográficas, teses em Congressos, artigos de doutrina e comentários de decisões do Tribunal de Justiça. 
É grande e valioso, portanto, o vosso currículo.

Acrescentem-se, ainda, outras inúmeras funções desempenhadas por V. Exa. no campo universitário, como a de Diretor da Faculdade de Direito da Universidade Mackenzie; de Reitor da mesma Universidade; de Membro do Conselho Universitário da Universidade de S. Paulo; de Membro da Comissão de Implantação da Pós-Graduação nas Faculdades da USP; e de Membro do Conselho de Reitores das Universidades Brasileiras.

Exercestes, pois, as funções mais elevadas no magistério universitário, desempenhando-as com altivez e serenidade, nunca se omitindo ou fugindo às lutas árduas e inesperadas, muitas vezes provocadas por situações independentes de vossa escolha.

O trabalho de V. Exa., Prof. Emérito PHILOMENo JoAQUim DA CoSTA, é notável e será modelo para todos quantos desejarem buscar ciência neste sagrado centro de cultura e brasilidade.

Orgulham-se os alunos do mestre que soube traduzir em linguagem clara, escorreita e erudita todos os segredos do Direito Comercial, campo das ciências jurídicas que se amplia celeremente, com aspectos novos à medida que as atividades sociais em geral e comerciais em particular se transformam rápida e profundamente.

Conseguistes um acervo de conhecimentos com talento e pertinácia, distribuindo-os perdulariamente a todos os vossos discípulos.

Por isso a vossa voz jamais permanecerá silenciosa nestas arcadas, mas será fonte permanente a recordar o exemplo e o ensinamento que marcaram a nobreza de vosso caráter e o valor do mestre estimado e por todos admirado.

Se o fruto depende principalmente da qualidade da semente, a árvore que aqui plantastes dará abrigo e o meio necessário para que os egressos desta Faculdade possam lutar nos cenários judiciários, políticos e universitários do país com vantagem e determinação.

Paulista de Piracicaba, a simpática e laboriosa cidade do nosso hinterland, herdastes de vossos antepassados a previsão e a vontade firme de vencer todas as dificuldades, não mais abrindo roteiros e semeando vilas, porém, espargindo cultura e valorizando o homem, inclusive lutando, em 1932, com armas nas mãos em defesa da lei e da liberdade. 
Peregrino de longa jornada, atingistes a fase culminante de vossa carreira.

Não posso, entretanto, Professor Emérito PHILomeno JoAQUIM DA COSTA, dizer agora a V. Exa. sede bem-vindo, porque nesta Casa sempre estivestes e dela nunca saistes, mas posso afirmar-vos que se ufana a Academia do Largo de São Francisco de seu filho ilustre e vos exalta como lídimo representante da plêiade de mestres que a honram e dignificam.

\section{Discurso de Agradecimento do novo Emérito}

E uma honra muito grande receber o título significativo de Professor Emérito desta Faculdade de Direito da Universidade de São Paulo. Constitui um galardão, em que o beneficiado é quem menos restringe o acerto do ato, porque, sabendo no fundo que não o mereceria, prefere mostrar-se agradecido; e é no reconhecimento que então se revelando de fato penhorado; deixa de criticar a mercê, mas a agradece

No ritual do recebimento do título figura a oportunidade para se dizerem coisas de relevância. Constitui o ato uma prova da mais acentuada intelectualidade. Os personagens devem enunciar mensagens e os pobres dos amigos mal pagos por tanto carinho com as suas presenças tão valiosas - eles dispõem-se a ouvir aquilo que aqui lhes é afirmado a título de questões importantes.

\section{I}

Como professor do presumido direito comercial procuramos iniciar as gerações acadêmicas no manuseio das regras, que balizam juridicamente as atividades humanas negociais.

Devemos dar algumas explicações preliminares àqueles, que nos honram com as suas atenções, visto como não são todos iniciados nos segredos e nas vielas das ciências jurídicas. Mantemos o mesmo propósito de sempre de explicar antes as coisas e depois prosseguir na exposição do assunto, que desejamos numa primeira parte desta nossa fala enfrentar. Queremos opinar sobre a questão momentosa da Subjetivação da Empresa.

$\mathrm{E}$, antes que os nossos amigos-leigos se arrepiem, dizemos que lhes explicaremos com a maior simplicidade a colocação do 
problema e do mesmo modo manifestaremos as nossas idéias, de tal arte que possam também acompanhar o nosso raciocínio e quiçá ter uma satisfação espiritual íntima.

Quando ingressamos para o professorado desta Casa, oferecemos oficialmente à sua douta Congregação, como demonstração presumida de nossos conhecimentos de direito mercantil, a tese sobre "Autonomia do Direito Comercial" Defendemos a inexistência desse ramo do direito. Os nossos examinadores não gostaram positivamente da conclusão. Não existe absolutamente nenhum desdouro em lhes atribuir, tantos anos depois, um comportamento de seu amor respeitável pela tradição.

Durante os séculos XIII e XIV os então mercadores conseguiram ver aceitos na coletividade os seus costumes de negócios. Eles faziam-se com novidades de institutos jurídicos por eles criados e com procedimentos mais rápidos e mais seguros do que aqueles decorrentes então de um direito romano, dito vulgar; as regras deste, trabalhadas pelo pensamento cristão pouco utilitário, adequavam-se mais a uma economia escravagista, sem uma idéia real, ou moderna, de mercado. Com o desenvolvimento econômico em seguida, os usos dos mercadores revelaram-se mais propícios à dinamização da vida. Acabaram no começo do século XIX por constituírem um Código de Comércio na maioria dos países, ao lado de um Código Civil, feito para as relações privadas não mercantis.

Aconteceu que os novos institutos jurídicos e as formas dos negócios comerciais invadiram paralelamente com o progresso prodigioso do mundo civilizado, toda a gente sem mais distinção entre personagem mercador e personagem não-comerciante. A fim de que todos tenham uma idéia clara do assunto, podemos lembrar que o cheque, que sacamos todos os dias contra os nossos respectivos bancos, já não constitui há muito tempo, um ato comercial privativo de quem fosse ou seja negociante. Desejamos apenas argumentar que um direito civil tradicional aceitou praticamente os institutos e as peculiaridades, que os mercadores de antanho criaram entre si, de tal modo que se pode asseverar cientificamente que já não existe mais razão para se falar academicamente que há um direito comercial distinto de um outro civil.

É por isto que no nosso País não se defende mais a elaboração de um novo Código de Comércio e, ou se tentou criar um Código Civil novo juntamente com um Código de Obriga- 
ções único (solução suíça de 1911$)^{1}$ ou se tenta criar um novo Código Civil unificado (solução italiana de 1942) ${ }^{2}$.

Do fato de se encaminhar a legislação para a unificação do direito privado pensamos extrair em primeiro lugar e sem maior importância a justificativa da denominação que demos no início destas palavras de presumido ao direito comercial; pensamos depois que essa explicação ajuda a entender a luta existente entre os privatistas, opinando uns pela inexistência de um direito comercial e entendendo outros que subsiste um direito das empresas, não se podendo falar em fusão do direito privado.

A luta baseia-se no fenômeno econômico incontroverso, existente em nossos dias, consistente em que a exploração sistemática de riquezas gera a empresa. E tal a sua força de atração ou a sua força centrípeta, que se revela ser um organismo, em torno do qual se desenrolam atos jurídicos constantes em grande quantidade, de modo a que se acabe por lhe reconhecer um ente, que se destaca da pessoa do seu dono.

Didaticamente é bem melhor darmos um exemplo bem simples, quase ingênuo, desse fenômeno, que todos reconhecem sob o ponto de vista econômico, mas que não conseguiu o reconhecimento, diríamos obstinado, dos juristas.

Uma fábrica de sabão necessita, para ser instalada, de dinheiro ou, como dizemos tecnicamente, de capital. O dinheiro pode provir de um cidadão ou de uma sociedade fundada para a exploração dessa atividade. Com o dinheiro os donos do futuro negócio cuidam de adquirir máquinas e demais utensílios. Promovem a sua instalação adequada. Contratam empregados. Compram as matérias-primas. Fazem enfim funcionar a indústria. Vendem seus produtos. Ou recebem logo o seu dinheiro ou sacam duplicatas para o recebimento posterior do preço. Apoiam-se em banco para depósitos, para cobranças e eventuais outras operações de crédito. Tudo isto passa a se repetir todos os dias pelos anos afora.

O transeunte descuidado, que passa pela frente da fábrica, pode ocasionalmente depositar nela o seu olhar descuidado, mais preocupado talvez com os seus palpites na próxima loteria

1. Projeto de Lei n. ${ }^{0} 3.264 / 65$ (versão opinada pela Comissão Caio Mario da Silva Pereira) e retirada mais tarde do Congresso Nacional pelo próprio Governo.

2. Projeto de Lei n. ${ }^{\circ} 634 / 75$ (versão opinada pela Comissão Miguel Reale) e paralisado na Câmara dos Deputados por motivos não muito convincentes. 
esportiva. O jurista, que o seja de verdade (e isto restringe bastante o seu número), ele vê a fábrica e pensa que lá dentro, todos os dias, existe uma série grande de negócios: compras de tudo quanto é necessário, pagamentos cada vez maiores de impostos e de salários; vendas em decréscimo constante em época de desajustamento econômico; recebimentos igualmente difíceis e uma quantidade enorme de atos, a fim de que a fábrica, se não for para a frente, que pelo menos se mantenha.

Então o jurista - aquele que seja de verdade - rememora que nessa fábrica existe um núcleo produtor de riquezas. Alguém está quotidianamente fabricando sabão. Em linguagem de direito pode dizer-se que ocorre uma atividade econômica organizada, que serve de certos meios para alcançar os seus objetivos.

Os meios empregados, ou seja, os componentes da fábrica propriamente dita, constituem aquilo que em direito se chama de estabelecimento. A atividade, que congrega os fatores da produção, é o que se denomina de empresa. Quem sabe possamos afirmar, depois da explicação, que empresa é a atividade constante na produção de riqueza.

Somos tentados a pedir aos nossos amigos que meditem um pouco nessa fábrica de sabão, daqui a uns trinta anos, por exemplo. Ela, a despeito da inflação crônica (ou por isto mesmo), ela, apesar das agressões das autoridades públicas, enfim, não obstante os fatores negativos, que se podem imaginar existentes num país muito distante, a fábrica desenvolveu-se e se engrandeceu.

Ninguém mais daqui a trinta anos quer saber quem a criou; os contemporâneos leigos enxergam então apenas a fábrica como uma atividade que sobreviveu às suas aflições; os juristas os verdadeiros - reconhecem tecnicamente que há uma velha empresa.

Indagamos agora e sem mesmo necessidade de transferirmos os nossos pensamentos para um futuro longínquo, quem compra sabão pensa em adquiri-lo da fábrica ou do dono da fábrica?

Não há dúvida de que com o tempo todos compram da fábrica, mesmo porque, morrendo ou mudando o dono, as compras prosseguem indiferentemente à pessoa que tenha sido o fundador. Isto acontece na maioria das vezes. Aliás, quando entramos numa loja ou num cinema, não o fazemos normal- 
mente porque o senhor João ou a Companhia Tal seja a titular do estabelecimento. $\mathrm{f}$ deste que o Governo cobra na verdade os tributos, que lhe são devidos.

Pensamos que seja agora possível compenetrarmo-nos do fenômeno econômico empresa. Podemos apreender que vivemos das empresas, porque sejamos seus empregados. Podemos entender que vivemos com as empresas, porque sejamos seus fregueses. Podemos perceber enfim que existem mesmo organismos em que o grande público ignora quem se coloque atrás deles.

Isto tem uma importância enorme para o jurista autêntico. Este é forçado a admitir que, havendo um conjunto de bens ativados na produção de outros ou de serviços úteis (loja de sapatos ou cinema de prestação de serviços de exibição de películas), esse conjunto de bens em produção de riquezas cria em sua volta um centro de relacionamento constante de pessoas e de interesses, em que a atividade calcada em bens é o que mais conta nesse contato permanente digamos de gente.

Chegamos a um ponto em que nos é possível perceber que a pessoa do dono do negócio interessa menos do que a quantidade de bens aplicados na atividade, digamos agora, empresarial.

Foi pois este deslizamento da maior projeção do estabelecimento em si em contato com as outras pessoas que fez surgir a proeminência da empresa sobre quem seja o seu proprietário. $\mathrm{E}$ esta sua deposição ou distanciamento fez-se sentir mais pronunciadamente quando se analisa a circunstância de que a empresa é administrada por empregados; a clientela trata com os gerentes e o fenômeno propriedade do estabelecimento fica praticamente escondido. Atua na realidade a empresa pelas pessoas que lhe prestam profissionalmente os seus serviços.

Todos os amigos, que se sacrificam em nos ouvir, compreendem conclusivamente que as grandes sociedades por ações, tendo um número grande de sócios, chamados acionistas, são dirigidas por executivos. Nos Estados Unidos a gente pode expressar que as imensas empresas não são de ninguém, a não ser que se considerem, num seu primeiro contato, os administradores, empregados de fato, e que, repetindo e salientando, são os executivos.

De tudo isto e em linguagem singela se pode extrair um princípio, que hoje tem a mais acentuada importância no ramo das ciências jurídicas, onde o governo não deve intervir, isto é, no direito privado; esse princípio consiste no problema do 
reconhecimento da personalidade jurídica à empresa, ou, por palavras técnicas, a subjetivação da empresa.

Quando alguém cria uma fundação, ele destina-lhe bens suficientes e lhe dá uma organização. Todas as pessoas compreendem que a fundação seja um ente capaz de direitos e de assumir obrigações. É um sujeito de direito. Quando muitas pessoas formam uma sociedade por ações, criam também um ente igualmente capaz de direitos e de obrigações; o patrimônio social responde exclusivamente pelos encargos assumidos pela sua diretoria, formada não raro de pessoas que nem são seus acionistas.

Verifica-se então que um conjunto de bens com destinação especial pode exemplificativamente formar um núcleo de atividades com responsabilidades próprias, totalmente separadas das suas pessoas formadoras.

Apesar disto existe generalizadamente uma resistência legislativa ao reconhecimento da personalidade jurídica da empresa. Mantém-se o conservadorismo de que é ente capaz de direitos e obrigações, de que em suma é pessoa com essa capacidade, o ser humano normal ou as associações ou sociedades constituídas segundo a formulação tradicional da lei.

$\mathrm{Na}$ hora, em que alguém recebe a láurea docente do mais alto grau, ele tem o dever de opinar sobre algum problema transcendental da sua especialidade. É por isto que, enfrentando a subjetivação da empresa, entendemos que ela tarda no seu batismo em texto de lei. ${ }^{3}$ Deixamos de ler propositadamente os rodapés, que fazem imaginar ilusoriamente que se enfrentou o assunto com alguma erudição. Nem por isto sone-

3. A empresa é essencialmente uma atividade (econômica; não é um ser intelectual (pessoa), nem um objeto de direito e nem uma relação jurídica. Não sendo uma das categorias de direito tradicionais, progrediu à sombra da personalidade das pessoas jurídicas, como meio de conseguir um seu destaque patrimonial das pessoas suas sócias. O escopo de lucro não lhe é com efeito essencial (GAETANO PACELLO, "A evolução do conceito de empresa no dir. italiano", n. 8, na Rev. Dir. Mercantil, n. ${ }^{\circ} 29(1978)$ 53) e sim a "economicidade". E economicidade entende-se como a organização da produção dirigida a um fim; capital e trabalho conjugados no mesmo sentido, elementos que JOSE CRETELLA JUNIOR ("Formas Jurídicas da empresa pública n..$^{\circ}$, na Rev. Forense, 253 (1976) 81) chamou de seu substrato. Finge-se majoritariamente a ostentação da "propriedade" da empresa pela sociedade, que a fundou. "Não se trata de uma heresia generalizada, mas antes de uma hipocrisia destinada a disfarçar as carências do direito" (CLAUDE DE CHAMPAUD "L'intreprise personelle de responsabilité limitée", n.o 18 no fím na Rev. Trimestr. Dir. Commercial, 1979/595). A subjetivaçāo da empresa adequa o Direito à Economia e às inconveniencias do risco, para incentivar de resto os empreendedores... com a limitação da responsabilidade civil de cada um. 
gamos a assertiva de que o nosso pensamento se concretiza a respeito no seguinte: a nossa legislação privada, conformando-se com a realidade dos fatos, deve admitir que a atividade organizada para a produção de riqueza seja também um sujeito de direito.

Na legislação comparada há o precedente da "Anstalt" do pequenino principado do Liechtenstein, situado entre a Suíça e a Alemanha. Ele, na verdade, admitiu a limitação da responsabilidade do empresário individual por questão de conveniência tributária. Procurou erigir-se em paraíso internacional da sonegação de impostos, admitindo que no seu território se instalem sedes de empresas, libertas de recolhimento de tributos e com o acréscimo da limitação da responsabilidade, mesmo quando seja uma pessoa física a sua única interessada. Não podemos outrossim omitir aquilo que se passa em alguns estados dos Estados Unidos; a legislação do Arkansas, Delaware, Illinois, Iowa, Kentucky, Maryland, Michigan, Minnesota, Missouri, Montana, Nebraska, Novo México, Nova Iorque, Oregon, Pennsylvania, Carolina do Sul, Wisconsin e Wyoming prevê a constituição da "one man company", ou seja, a sociedade de uma pessoa só 4 .

Todos percebem que a possibilidade de se constituir, digamos impropriamente, uma sociedade de uma única pessoa é o mesmo problema de uma pessoa qualquer formar separadamente um negócio; é no fundo uma questão de emprego de palavras diferentes, que aportam, que conduzem à admissibilidade da institucionalização de um negócio, que se mexe, que se agita, que atua enfim por si só no campo da responsabilidade patrimonial. Se nós podemos isoladamente constituir uma sociedade de responsabilidade limitada, isto quer dizer afinal que poderemos separar do nosso patrimônio uns tantos bens e aplicá-los num negócio qualquer, vivendo essa atividade separada de nós mesmos. Será um patrimônio separado no seu sentido puro.

Os juristas de tradição romanista hesitam em consagrá-lo e os legisladores não recebem destarte o impulso indispensável para o porem em letra de forma da lei.

A matéria é muito importante. É importante porque na prática se encontra de fato consagrada. Ninguém hoje em dia arrisca irresponsavelmente a sua fortuna particular nos azares

4. "Apud" Felice Santonastaso, "Limitazione della responsabilitd e impresa individuale a responsabilità limitada (Riflessioni sull'Anstalt del Liechtenstein)" na Riv. Dir. Comm. 1969, I, nota 65 à pág. 337 . 
de uma atividade de produção constante ou de bens ou de serviços. Existem aos montes as sociedades fictícias por ações ou ditas de responsabilidade limitada em que o dono respectivo detém 99,999\% do capital. ÂNGELo GRISOLI produziu a sua monografia magnífica Le Societa con un Solo Socio ${ }^{5}$.

Se a universidade é forja do progresso científico, até mesmo nas ciências sociais, ela deve fazer sentir-se. Deixamos na solenidade desta noite o registro de que se acabe com a simulação de se admitir a limitação da responsabilidade patrimonial nos negócios, quando tiver apenas a forma de uma sociedade. SYLVIo MARCONDES, na melhor monografia existente entre nós sobre a matéria, mostrou que se pode tomar uma das soluções teóricas seguintes: ou a personalização da empresa individual (solução subjetiva), ou a criação independente do patrimônio de afetação ou separado (solução objetiva) ${ }^{\circ}$. SYlvio MARCoNDES insinuou conclusivamente ${ }^{7}$ que a técnica jurídica dissocie a titularidade substancial de direito da titularidade formal de direito. Em linguagem profana esse colega eminente propugnou por que a empresa detenha os atributos da personalidade, mas que a sua representação, para efeitos processuais, seja dada ao empresário, isto é, o patrimônio, por este separado e criado, tem os benefícios e os ônus dos negócios e esse interessado tem o direito-dever de agir por sua conta.

Este nosso escrito despretensioso encontrava-se já redigido para a sua leitura. Modificamo-lo para introduzir um parêntesis bastante triste e muito desagradável: SYlvio MUTSO-HiTo MARCONDES MACHADO - mestre nesta Casa - deixou de existir há poucos dias, isto a 4 do corrente. Perdemos subitamente o colega maior, ficamos sem o convívio do companheiro da turma longínqua formada em 1929 e sobretudo nos encontramos privados do grande amigo. SYLVIo MARCoNDES foi SYLVIo Mutso-hito MARCONDES MACHADo. Seu pai, entusiasta da pugnacidade dos japoneses na guerra contra os russos, em 1905, batizou o seu filho então nascido com um segundo cognome, a eternizar o ardor paterno por uma longínqua luta, que projetou definitivamente o Japão no quadro das grandes potências.

Entre nós e ele havia também, embora de somenos, a coincidência de portarmos nomes diferentes, devidos a entusiasmos

\footnotetext{
5. De que fizemos apreciação na Rev. Dir. Mercantil, n..$^{\circ}$ (1972), págs. 161 e segs.

6. Limitaçāo da Responsabilidade de Comerciante Individual n..$^{\circ} 103$, pág. 278 e n. ${ }^{0} 106$, pgs. $283 / 4$, respectivamente.

7. Obra citada, n. $0^{\circ} 120$, pgs. 330 e segs.
} 
paternos. Ele, repetindo, foi Mutsohito, testemunhando o entusiasmo de seu pai pelós japoneses em 1905. Nós, ao nascermos, em cumprimento a promessa paterna de sermos o primogênito varão, tivemos masculinizado o nome da santa, que a folhinha registrava, quando viemos ao mundo.

Espiritualmente, tal como no início da aria da ópera "uma lágrima furtiva nos nossos olhos brotou" Os juristas têm também alma, também choram. Ficam tristes tais como os outros mortais. $\mathrm{O}$ nosso parêntesis foi para confessarmos todo o nosso pesar pela perda de Sylvio Mutsohito Marcondes Machado.

Mudamos abruptamente a mensagem desambiciosa das nossas palavras. Passamos a cogitar do abandono do ensino superior.

Devemos rememorar que nos últimos quinze anos se deram no nosso País, dois acontecimentos do maior relevo: o movimento revolucionário de 1964 e o nosso desenvolvimento econômico bem acentuado. 0 primeiro estabeleceu um regime de força sob a bandeira da moralização da vida pública e o segundo criou, entre outras coisas, a explosão da quantidade dos jovens candidatos às universidades.

Somos daqueles que entendem até hoje que a rutura da constitucios alidade autêntica existente em 1964 se consagrou como uma nossa necessidade política. Repetimos, por outras palavras, que a atuação militar de então teve de início o apoio das camadas responsáveis da nossa gente.

Somos daqueles que entendem mais do que nunca, em relação à formação imanente da nossa mocidade intelectual, que o regime, tendo tantos meios excepcionais em suas mãos, enveredou pelo caminho da desqualificação da instrução superior. A ignorância pré-existente agigantou-se. Diríamos, com o devido respeito, que o Ministério da Educação, da Cultura e dos Esportes permanece esportivo ou, se permitirem, continua acéfalo. Ouvimos dizer-se irresponsavelmente que se conseguiu uma fórmula de supressão dos excedentes.

Todos sabem que todos os anos se estabelece no sul do País, uma autêntica maratona dos estudantes de cambulhada, à procura de uma vaga de preferência numa universidade ou pelo menos numa faculdade isolada: As autoridades arranjaram orgulhosamente lugares para todos. Para tanto 
elas facilitaram a proliferação de escolas e transformaram os exames vestibulares em simples concurso classificatório; o candidato que alcance a nota 0,1 (um décimo), isto é, que escape da nota 0 , é obrigatoriamente admitido na lista geral da classificação de ingresso à faculdade. Aconteceu que a enxurrada de jovens despreparados na verdade penetrou no patamar do ensino superior. Todos sabem também que o ensino secundário não chega a ser inferior, porque é uma vergonha. Não mantemos intuitos demagógicos; o amor pela cátedra acrisolou a objetividade na análise fria das coisas da educação pública. Como examinadores, juntamente com o grande Flaminio FAvero - autêntico varão de Plutarco - tivemos na Faculdade de Direito de Universidade particular, onde ensinamos durante muitos anos, tivemos um candidato ao seu ingresso, em que na prova oral, ainda não suprimida, lhe perguntamos, depois de indagações fáceis frustradas, o que significava a primeira palavra do texto em inglês, que era simplesmente a lera "i" em maiúsculo. Ele disse-nos, com o seu melhor ar vitorioso que era o algarismo um em romano!

Essa confusão, para escrever o menos do rapaz audacioso, feita do pronome -eu- com a demonstração de cultura da existência da numeração romana revela o despenhadeiro do chamado ensino secundário. Não se objete que existem sempre jovens hermeticamente ignorantes. Sabemo-lo. Mas a aplicação estatística da medida do despreparo da nossa juventude revela o seu grau muito elevado, para não se escrever assustador.

As autoridades arranjaram orgulhosamente lugares nas escolas superiores para todos. Elas proclamam que desapareceram os estudantes que não os conseguiam. Não se ouvem mais os clamores daqueles que fizeram o seu curso secundário (ou que dizem que o fizeram) e não tiveram possibilidade de prosseguirem.

Esses clamores assemelham-se à grita daqueles que bradam, pensando que o barulho tenha poder taumaturgo de convencimento.

O pior consiste em que as autoridades arranjaram orgulhosa e ineptamente a instituição de um período inicial, nos cursos universitários, de revisão preliminar de certas matérias do ciclo secundário. Reensina-se por exemplo, português, ou trigonometria, conforme a faculdade. A carga horária de qualquer escola manteve-se. Dessa carga horária subtraíram-se horas 
aplicadas no reestudo de disciplinas já estudadas teoricamente no curso secundário, onde os novos universitários deveriam ter aprendido o suficiente para compreenderem as explicações pos. teriores dos mestres já em grau superior. O tempo de estudo universitário propriamente dito diminuiu e passou a ser ministrado filosoficamente ou de fato a gente que se reconheceu despreparada. Entrou-se num regime universitário duplamente prejudicial: oficializou-se a admissão de moços despreparados e se achatou mais o tempo para a transferência a eles dos conhecimentos científicos.

Orgulhamo-nos de pertencermos à Universidade de São Paulo também porque ela vem timbrando em recusar essa forma de achatamento do ensino superior; mas ele mantém soberanamente o País num subdesenvolvimento africano ou sul-asiático. E uma pena e talvez as pessoas de bem compreendam que na hora da outorga de um título de professor emérito o seu beneficiário consigne o seu protesto contra este estado de coisas.

Uma personalidade nas altas esferas da instrução pública telegrafou-nos há meses, pensamos que em virtude de uma publicação livre que fizemos por um jornal daqui; a propósito da divulgação da notícia de nossa vitória completa em pleito, que ajuizamos contra uma pitoresca entidade mantenedora de universidade particular, tecemos muito ligeiramente considerações sobre o prejuízo do País com o adiamento da formação honesta de um escol científico e tecnológico. O ensino superior particular constitui no mais das vezes um comércio ignóbil e o ensino superior oficial representa não raro um asilo para componentes de famílias consideradas importantes; vimos sobretudo isto no norte do País. A personalidade aludida pediu-nos sugestões que pudessem ser aproveitadas.

Ousamos, num clima naturalmente respeitoso, dizer à guisa de resposta que as nossas autoridades devem quanto antes promover: 1 - encerramento das atividades de qualquer escola superior particular ou oficial municipal, que não possua condições honestas de continuação; isto seria apurado não por funcionários do ministério e sim por professores concursados de universidades federais ou estaduais. 2 - imposição às chamadas entidades mantenedoras de escolas ou universidades de fornecimento gratuito de prédios e instalações das unidades por elas sustentadas e sua proibição de intervir no orçamento escolar; os salários dos professores fixam-se pelos padrões da localidade da escola e as taxas serão cobradas na medida do seu pagamento e das despesas contingentes; os melhoramentos 
serão introduzidos obrigatoriamente pela entidade mantenedora. 3 - estabelecimento do professorado concursado honestamente por provas e por títulos, como praticado isoladamente pela Universidade de São Paulo. 4 - fixação em qualquer exame da natureza de sua eficiência com um índice mínimo de aproveitamento; quem não o alcançar será, conforme o caso, eliminado ou reprovado. 5 - restabelecimento do caráter eliminatório dos exames de ingresso para os conselhos regionais de profissões superiores; o diploma de conclusão do curso será apenas um documento que permite ao formado prestar o concurso indispensável para o exercício da profissão pretendida. E 6 - Supressão do Conselho Federal da Educação, ou pelo menos, refundi-lo "de fond en comble", de tal arte que os grupos de pressão e outras estratificações porventura existentes, sejam eliminadas.

Ou nós aprendemos a ser corretos ou quem sabe, parodiando Eçá de Queiroz, no frontespício da sua adorável "A Relíquia", consignemos contristados que continuaremos a ser um montão de lama a rolar pelo espaço com basófia de nação.

\section{III}

Mudamos abruptamente de novo a mensagem desambiciosa das nossas palavras. Passamos a cogitar da redemocratização do País, matéria bastante delicada. É delicada, porque os círculos responsáveis preferem tergiversá-la. Resolve-se evitarem aborrecimentos imaginários e imaginados. Desconversa-se quando muito, quando não se prefere elogiar aquilo que aí está e que tão cedo, não pretende mudar-se.

Quem recebe a láurea de professor-emérito da melhor Faculdade de Direito podia abrigar-se no aconchego de tão grande honra e pensar silenciosamente que a outros caberia no campo apolítico pugnar contra o sistema governamental atual do País.

Não nos enganemos acerca da nossa realidade. Todo o regime de força alimenta e faz prosperar a desonestidade administrativa. Todo o regime de força vive auto-elogiando-se, destacando os perigos, que afirma afastar.

Não mantemos obviamente qualquer prevenção contra quem quer que seja; o convívio durante tantos anos com os livros argamassou ou edificou a convicção de que somente a liberdade de discussão permite a aceitação de regras de comportamento coletivo ou que permite identificar o fana- 
tismo desequilibrado. As primeiras conseguem o milagre do carisma da aceitação e o segundo nos arma vitoriosamente no afastamento das suas idéias.

Desejamos ser explícitos, porque as pessoas bem postas na vida, por temor por exemplo hipotético ao comunismo, só enxergam nos excessos policiais, também a título de exemplo hipotético, a manutenção de uma ordem estável e a derrota dos mal-intencionados. Quem está bem economicamente é conservador por egoísmo e fantasia indistintamente subversões nos protestos daqueles com bons ou com maus desígnios. Reconheçamos por tolerância científica e por amizade que a parcela das pessoas contrárias às reclamações não constituem a maioria. E afirmemos sobretudo que uma liberdade de discussão carrega felizmente consigo o bem da satisfação do anseio de ninguém ser amarrado, enjaulado pelos outros homens.

Dissemos e desejamos repetir: num clima civilizante 0 desenvolvimento geral opera-se efetivamente pela tolerância das discussões e então, por convicção, em hora de tertúlia intelectual de tão grata significação, não podemos omitir uma alusão à prestidigitação, para não aludirmos à escamoteação, do estado político atual. Nesta Casa, com "c" maiúsculo, aprendemos e ensinamos o Direito. Empregando linguagem profana, dizemos que aqui se ensina aos cidadãos serem corretos por bem e, se não o forem, serem punidos pela desobediência. A coletividade, o povo, todos nós enfim, podemos e devemos entender que o rodízio imposto de certos cidadãos (até mesmo dentre eles de corretos e patriotas) na direção geral das coisas públicas não é democracia. Convenhamos com CHURCHILl que ela é uma das piores coisas que o homem inventou, mas que até agora ele não conseguiu criar coisa melhor. Convenhamos que num regime, em que a direção central refaz sempre a seu jeito as regras de escolha dos depositários do poder público, não existe a democracia. Democracia é forma de governo, em que o povo escolhe diretamente os seus dirigentes, sem subterfúgios ou casuísmos.

Democracia para quê? perguntam os comprometidos, indagam os enriquecidos e averiguam os fracos.

Respondemos: a democracia é necessária para que os desregramentos nas coisas públicas não proliferem e permaneçam impunes; é para que, por hipótese, a construção de uma estrada de ferro do aço, que assim se chame, não consuma as montanhas de cruzeiros alcançados por empréstimos externos, para a sua efetivação e novos cruzeiros aos milhões lhe sejam 
aplicados e nem se saiba quantos mais estariam faltando. Respondemos: a democracia é necessária para que não continue o aumento dos impostos para serem pagos somente pelas zonas mais desenvolvidas do País e o produto da arrecadação beneficiar apenas os círculos dirigentes das zonas menos desenvolvidas. Respondemos: a democracia é necessária para que os cidadãos mais equilibrados da coletividade não mantenham a aversão pelas coisas públicas. Respondemos: a democracia é necessária para que os jovens não tenham que se submeter ao opróbrio das forcas caudinas, bajulando poderosos postiços, para se dedicarem às coisas governamentais. Reconheçamos que para a implantação da nunca assaz aplaudida Usina de. Itaipu, reconheçamos que para a extração tão auspiciosa do ferro da Serra dos Carajás, reconheçamos que para a exploração ótima do alumínio do Tucuruí, reconheçamos enfim que para isso e para o mais de bom que exista a competência e o proveito por aqueles que provenham de um regime de coisas claras seriam bem maiores. É a fatalidade da superioridade do jogo livre de interesses sobre os resultados das coisas realizadas em clima de círculos fechados.

Perdoem-nos os que nos ouvem em razão dessa incursão ao setor político. A Faculdade de Direito goza de renome, porque também alguns dos seus filhos sentem que, neste ambiente respeitável dos reposteiros de veludo carmin, o clima do trato das coisas é de desempeno. Ninguém se arma de uma lança e investe contra moinhos de vento, mas alguém deve dizer as coisas pela versão que as tem consagrado através dos séculos.

\section{IV}

Mudamos abruptamente por fim a mensagem despretensiosa das nossas palavras. Falamos como jurista, opinando pela subjetivação da empresa, ou seja, entendemos que tarda a consagração de um núcleo de atividades econômicas ter a qualidade de um ente independente, capaz de direitos e de obrigações. Falamos como professor, entendendo que o ensino superior demanda urgentemente o estabelecimento da sua autenticação. Falamos, como político, julgando que o País necessita de retornar logo a uma democracia sem adjetivos. Desejamos encerrar as nossas palavras, cuidando, já como cidadão, de combatermos os extremismos.

Os comunistas, ou melhor os fascistas vermelhos, reivindicam intensamente liberdades democráticas. Fazem-se sentir nas redações de jornais como adversários do estado atual político 
das coisas. Pixam os muros claros das residências com expressões duvidosas de uma licenciosidade incerta.

Do mesmo modo como a perpetuação de um grupo no poder governamental necessita de ser combatida, também a minoria insignificante dos adeptos, que se dizem do marxismo, precisam de ser enfrentados. Há - parece - um certo temor das pessoas se dizerem antifascistas. Somos daqueles que entendem que é indispensável proclamar todos os dias que os males de um fascismo verde ou rubro se medem pela perspectiva da instalação de um regime de opressão integral. Uma camarilha assenhora-se do poder pela força; disfarçam o seu exercício em nome dos trabalhadores escravizados e todos são deles meros cativos, simples servos.

Não devemos esquecer que os extremistas só conseguem comunicar-se com os indiferentes quando e onde o regime político, que apregoam, não se instalou. Preferem ficar fora deles. Não se mudam para os países onde o extremismo se instalou. São periquitos a fazerem barulho. É justo que chalreiem ou pipiem, mas devem saber que os seus gritos servem apenas de aviso para o seu distanciamento.

$\mathrm{Na}$ hora em que recebemos o título de professor emérito da melhor e mais renomada Faculdade de Direito do País, entendemos que os longos anos de estudos, convivendo com a mocidade acadêmica, nos impunham que assumíssemos posições, sem temor aos desagrados. Numa escola de ciências jurídicas não se pode tolerar a implantação de regime de força. Os comunistas não costumam ser cidadãos produtivos. Pensam que conseguirão ser chefes dos grupos dirigentes. Alimentam via de regra essa ambição, desbaratando talento, que bem se aplicaria numa implantação de democracia, caracterizada pela formação popular dos corpos governamentais. Os comunistas devem convencer-se de que a democracia não é meio de destruição da Família e da Pátria.

\section{V}

Chegamos ao termo das nossas considerações. O formalismo desta solenidade impôs-nos a conveniência do trato de assuntos intelectuais. Fizemo-lo canhestramente. Procuramos agora desculparmo-nos. No conto de ANATOLE France, "Le Jongleur de Notre Dâme", o prestidigitador que, outrora nas feiras da Idade Média, escamoteava e se contorcia nas suas exibições circenses, foi visto certo dia de cambalhotas em frente à ima- 
gem de Nossa Senhora, na cela do convento a que se recolhera; respondeu aos companheiros religiosos que era o modo pela qual sabia cultuar a sua santa. Temos-nos já valido desta comparação em vezes diferentes. Agora surgiu outra e solene. Para agradecermos a honraria só sabíamos contorcionar com considerações do nosso galho.

Há duas alegrias enormes que não podemos ocultar. Uma é o significado da saudação proferida pelo professor JoÃo BAPTISTA DE OLIVEIRA E Costa JÚNIOR. É o caro Costinha para os íntimos. A beleza e a representatividade das homenagens valem por aqueles que saúdam. $O$ nosso querido mestre de medicina legal soube na sua vida trilhar somente a linha reta. Diz-se em geometria que é a distância mais curta entre dois pontos. Na vida humana é o percurso mais longo e difícil de se trilhar. Costinha, excetuados os defeitos dos exageros do seu coração absorvente, chega ao termo do seu professorado com a cerviz indobrada, olhos cintilantes para a frente, com a consciência plena do dever cumprido. É uma honra tê-lo como colega, é uma recompensa tê-lo como amigo e é uma felicidade imensa ter sido por ele saudado. Depositamos aos seus pés o ramalhete das flores eternas do nosso agradecimento cordial. Aos caros colegas da douta Congregação deixamos também a consagração do nosso mais intenso reconhecimento; a nossa obra maior já iniciada, ventilando as sociedades anônimas e que esperamos alcance vários volumes, surgiu dedicada "à minha indômita Faculdade de Direito da Universidade de São Paulo". Pensamos constituir o melhor testemunho do nosso afeto por esta "velha sempre nova Academia"

Há que falar da segunda alegria, que jamais ocultaríamos. Pedimos aos que nos ouvem com tanta resignação que nos compreendam. Repetimos que os juristas têm também alma. É o sentimento íntimo das coisas. Tendo alma, temos um pouco de compreensão. Tendo compreensão, temos um pouco de reconhecimento.

Então nós perguntamos a nós mesmos: se esta solenidade tem tão alta significação, a quem devemos nos dirigir para encontrar como causa remota a sua maior colaboradora?

Fomos boêmios e não devemos levantar o véu da austeridade que necessita envolver um professor desta Casa. Chegamos a pertencer, apesar de arrimo jovem de família, às metralhadoras pesadas do Batalhão 14 de Julho no Movimento Constitucionalista de 1932, tendo recebido batismo de fogo. Mas a nossa vida endireitou mesmo quando Yolanda atravessou o 
nosso caminho. Com os nossos quatro filhos homens, as nossas noras e com os nossos netos, ela dirige o lar com o seu sorriso e com o seu carinho. Só existe um meio de prosseguir.: é submeter-se ao império delicioso do seu incomensurável bem-querer.

Os juristas têm também alma. Numa demonstração de fraqueza diríamos aos caros amigos que o incômodo que lhes causamos se filia à dedicação da minha esposa, porque ela tem artes que me trouxeram a esta solenidade.

A todos empenho a segurança do meu reconhecimento profundo. 